\title{
EFFECTS OF THIAMETHOXAM ON VESPULA GERMANICA (F.) (HYMENOPTERA: VESPIDAE)
}

\author{
Ahmed KARAHAN ${ }^{1 \odot}$ Fatma Nur SAHPAZ $^{2} \odot$ Mehmet Ali KUTLU $^{3} \odot$ Ismail KARACA $^{4 * \odot}$ \\ ${ }^{1}$ Çobanlar District, Ministry of Food, Agriculture and Livestock, Afyonkarahisar, Turkey \\ ${ }^{2}$ İstanbul University, Faculty of Veterinary Medicine, Department of Parasitology, İstanbul, Turkey \\ ${ }^{3}$ Bingöl University, Faculty of Veterinary, Department of Pre-clinical sciences, Bingöl, Turkey \\ ${ }^{4}$ Suleyman Demirel University, Faculty of Agriculture, Department of Plant Protection, Isparta, Turkey
}

"Corresponding Author: ismailkaraca@sdu.edu.tr

\begin{abstract}
Damage of pesticides used in agriculture on non-target organisms (except honey bees) is not sufficiently considered and neglected. Studies showed that wild bees, like honey bees, were also affected by pesticides. Wild bee species should also be protected because of their importance in pollination and biological control and also in order to protect biodiversity. Effects of pesticides on wild bees should be investigated without delay and precautions should be taken to protect the generations of wildlife. In addition, while increasing the agricultural areas, habitat for wild pollinators should be established.

In this study, effect of Thiamethoxam, an agriculturally active agent in the neonicotinoid group, commonly used in agriculture fields, on the European wasp (Vespula germanica) was investigated. For this purpose, 2 molar carnationflavored syrup in a petri dish was placed in a field where wild bees are frequent, and wild bees had got accustomed there. Trial doses were prepared with thiamethoxam dose commonly used in agricultural areas $(15 \mathrm{ml} / 100 \mathrm{~L}$ water) and $50 \%$ dilutions of this dose $(15.00,7.50,3.75,1.87,0.93,0.46,0.23,0.12,0.06 \mathrm{ml} / 100 \mathrm{~L}$ water $)$ and fed in 2 molar syrup. Those who returned to the carnation petri dish after feeding were recorded at the 1st, 4 th and 24 th hours.

At the end of the study, bees fed with $15.00,7.50$, and $3.75 \mathrm{ml} / 100 \mathrm{~L}$ doses of the pesticide all died. One hour after pesticide ingestion, $84.73 \%$ of the control group and $13.33 \%$ of the bees fed with $1.87 \mathrm{ml} / 100 \mathrm{~L}$ dose, were alive and returned to the syrup petri dish.
\end{abstract}

Keywords: Pesticide, Neonicotinoids, Thiamethoxam, Vespula germanica

Received: 14.11.2017 Accepted: 03.12.2017 Published: 20.12.2017

\section{INTRODUCTION}

Insects are important pollinators of wild flowers and cultivated plants $[1,2,3]$. The decline of pollinators, which are effective in crop production, in recent years has caused a concern in the field of international agricultural production due to the economic contribution and services they provide [4]. Without sufficient pollination, the source of many nutrients and critical food in the ecosystem will soon disappear [5]. In many countries, the diversity and number of wild pollinators in agriculture has decreased [6]. With the increase in agricultural and urban areas, the reduction of natural habitats and nutrient sources of wild bees is the biggest impact on the worldwide decrease of the wildlife population [7]. The living area of the wild pollinators is neglected while the agricultural land is increasing [8].

Pesticides are used to protect cultivated plants, but sometimes affecting off-target insects [9] and causing beneficial insects to be damaged and populations to be reduced [10]. In recent years, neonicotinoids are the most commonly used insecticides [11] and have become one of the causes of bee death worldwide at the onset of their use in agriculture [12].

Neonicotinoid insecticides have been identified in underground waters, off-target plants and bee products $[13,14]$. Neonicotinoid residues in nectar and pollen areas are indicated as one of the potential factors that cause the decrease of bee populations [15]. It has been found that the bee populations exposed to thiamethoxam are more susceptible to decrease and disappear [16].

Almost all of the investigations on the toxicity of neonicotinoids on bees were carried out on the honey bee, Apis mellifera [17], because honey bees are frequently exposed to neonicotinoids [18]. 
It has been determined that other bee species are more susceptible to selective pesticides than Apis mellifera [19].

Very little information is available on the effects of neonicotinoids on predator insects which has an important role in the functioning and biological balance of the ecosystem [20]. In this study, effect of thiamethoxam, a widely used insecticide in the control of agricultural pests, on the European wasp (Vespula germanica) [21, 22], which is one of the most common wasps in Turkey and important for biodiversity were investigated.

\section{MATERIALS AND METHODS}

The main materials of the study were Vespula germanica and insecticide Thiamethoxam, belonging to neonicotinoid group, commonly used in agriculture fields [23]. Doses $(15.00,7.50,3.75$, $1.87,0.93,0.46,0.23,0.12,0.06 \mathrm{ml} / 100 \mathrm{~L}$ water) were prepared by diluting $50 \%$ of the thiamethoxam dose $(15.00 \mathrm{ml} / 100 \mathrm{~L}$ water $)$ commonly used in agriculture, and were given to bees in 2 molar syrups.

Two molar carnation-flavored syrup was placed in a petri dish in an area where the wasps are frequent and the wasps were accustomed to it. Thorax and abdomen of the bees were marked with different water-insoluble colors [24].

Marked bees were collected in small plastic boxes, and healthy bees were separated after one hour. The bees were then fed with 5 microliters of
$2 \mathrm{M}$ syrups with the different doses of the insecticide and were marked with different colors. The bees were kept in the dark and in the light each for 15 minutes and then they were released to the area where the petri dishes with the carnation fragrant syrups were kept. Observations were made after 1, 4 and 24 hours and the bees returning to the petri dishes were noted. Each observation lasted 30 minutes. By this way, the number of the visits of the bees fed with different doses and controls were recorded. Experiments were established in 3 replicates for each dose, with 15 bees per dose, with a total of 150 bees.

As a result of the experiments, the responses of the bees to different insecticide doses were determined by regression analysis.

\section{RESULTS AND DISCUSSION}

All the bees fed with the $15.00,7.50,3.75 \mathrm{ml} /$ $100 \mathrm{~L}$ water doses of the pesticide died, so regression analyses were made with the results obtained with the other doses.

\section{Relationship Between Dose and Return}

After 1 hour of feeding with the pesticide, only $13.33 \%$ of the bees fed with the $1.87 \mathrm{ml} / 100 \mathrm{~L}$ water dose returned, while $86.67 \%$ of the bees in the control group returned. The regression graph of the relationship between the insecticide doses and returning bees is given in Figure 1.

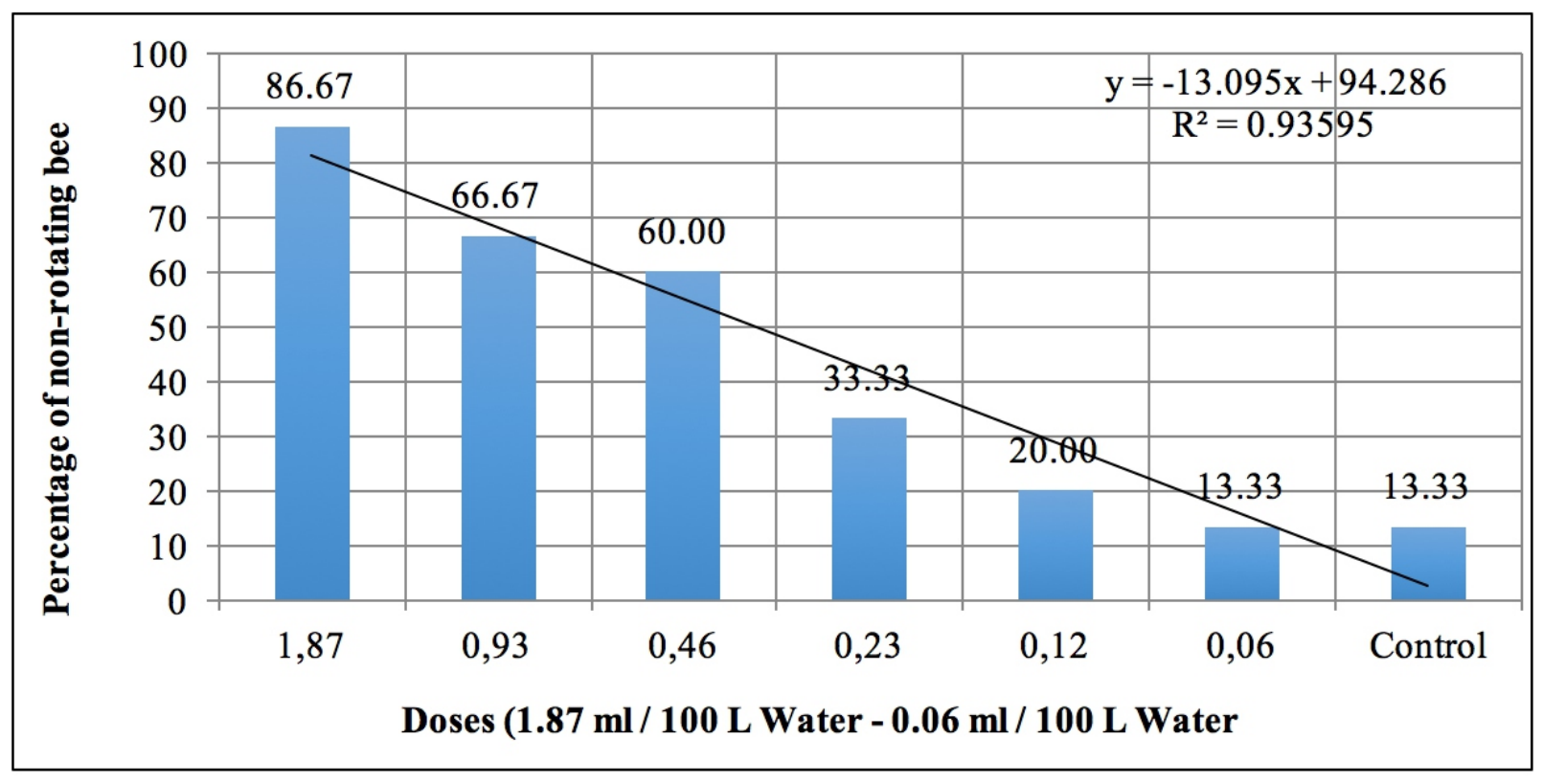

Figure 1. Relationship between the insecticide doses and rate of the bees which did not return one hour after feeding with the different doses of Thiamethoxam. 
As can be seen in Figure 1, observations made at the end of the first hour showed a high correlation between the different doses of the chemical and the rates of the returning bees. The rate of the bees returned decreased with the increasing doses. The relationship was determined as $\mathrm{R}^{2}=0.936$.

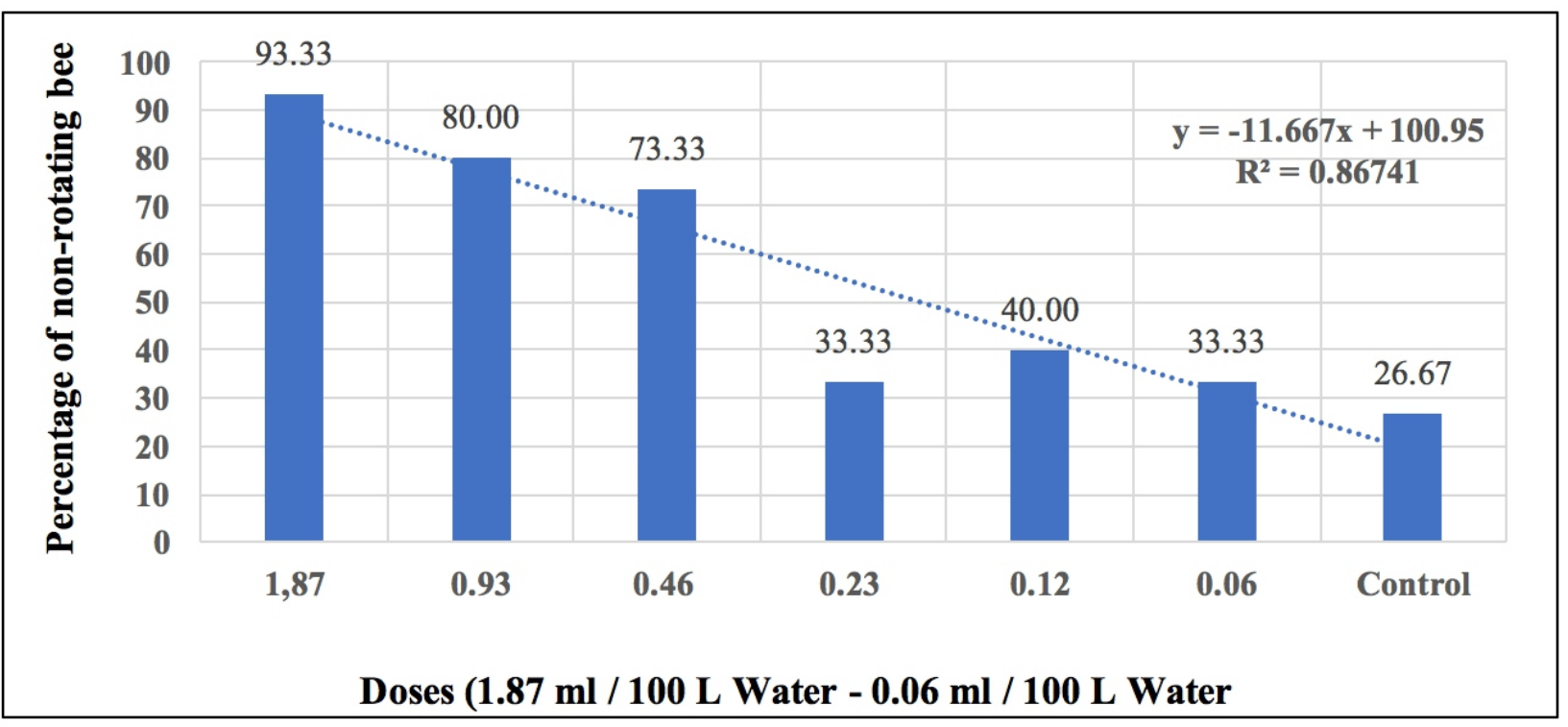

Figure 2. After 4 hour percentage of non-returning bees and regression graph.

In Figure 2, at the end of 4 hours, in Figure 3 at the end of 24 hours, graphs of the relationship between doses and percentage of non-returning bees were given.

At the end of 4 hours, $26.67 \%$ of the bees in control group and $93.33 \%$ of those fed with 1,87 ml/100 L water dose did not return. As the dose increased, the rates of returning bees decreased and the percent of the relationship was found to be $\mathrm{R}^{2}=0.8674$.

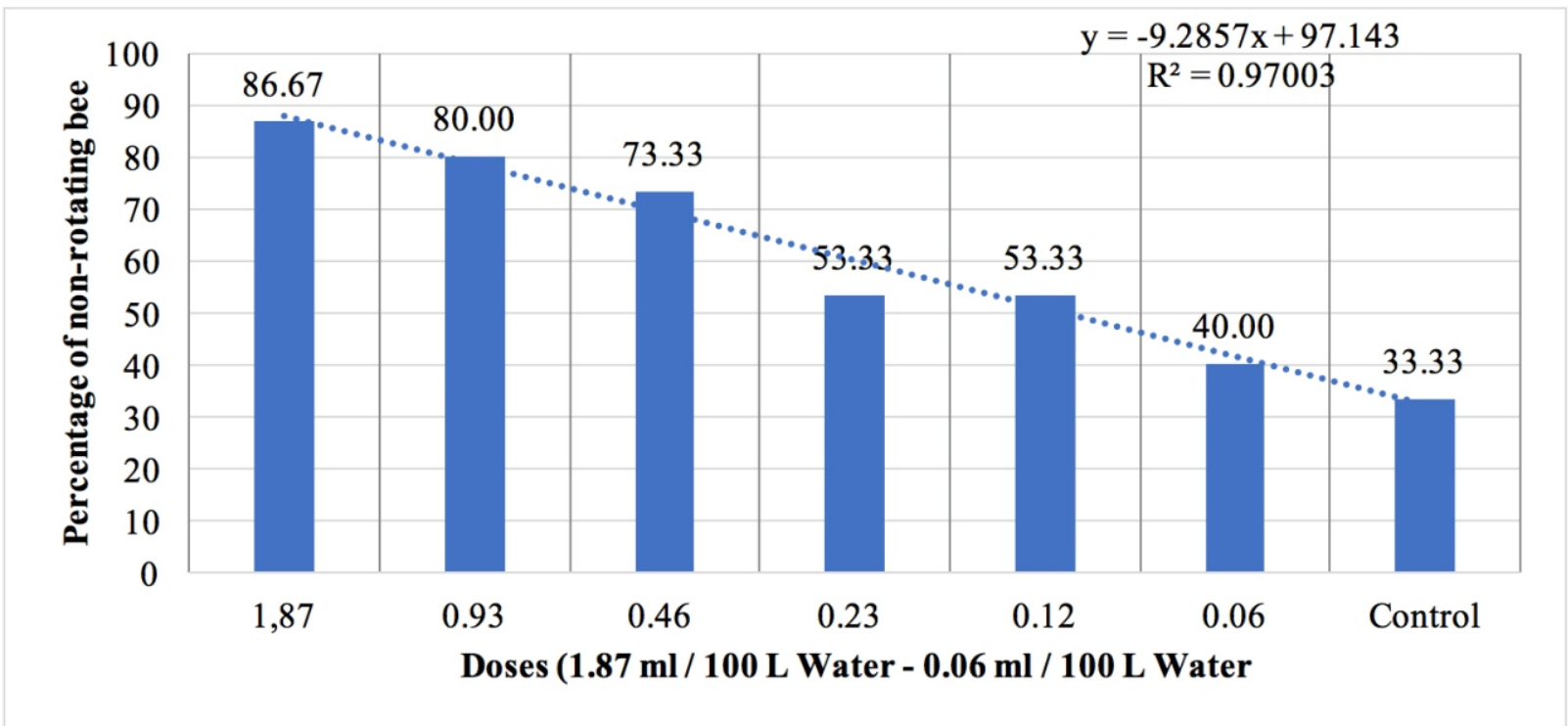

Figure 3. After 24 hour percentage of non-returning bees and regression graph.

As seen in Figure 3, at the end of 24 hours, 33.33\% of the bees in control group and $86.67 \%$ of those fed with $1.87 \mathrm{ml} / 100 \mathrm{~L}$ water dose of the pesticide did not return. The relationship between the rates of bees which did not return and insecticide doses was found to be quite high $\left(\mathrm{R}^{2}=0.97\right)$. 


\section{Relationship Between Dose and Number of Visits}

In Figure 4, averages of the visits of the bees per half-hour observation period to the petri dishes containing carnation-flavored syrup were given. The number of visits of the bees fed with 1.87 and $0.93 \mathrm{ml} / 1001$ water doses of Thiamethoxam were rather low, while those of the bees fed with lower doses were similar with the ones in control group.

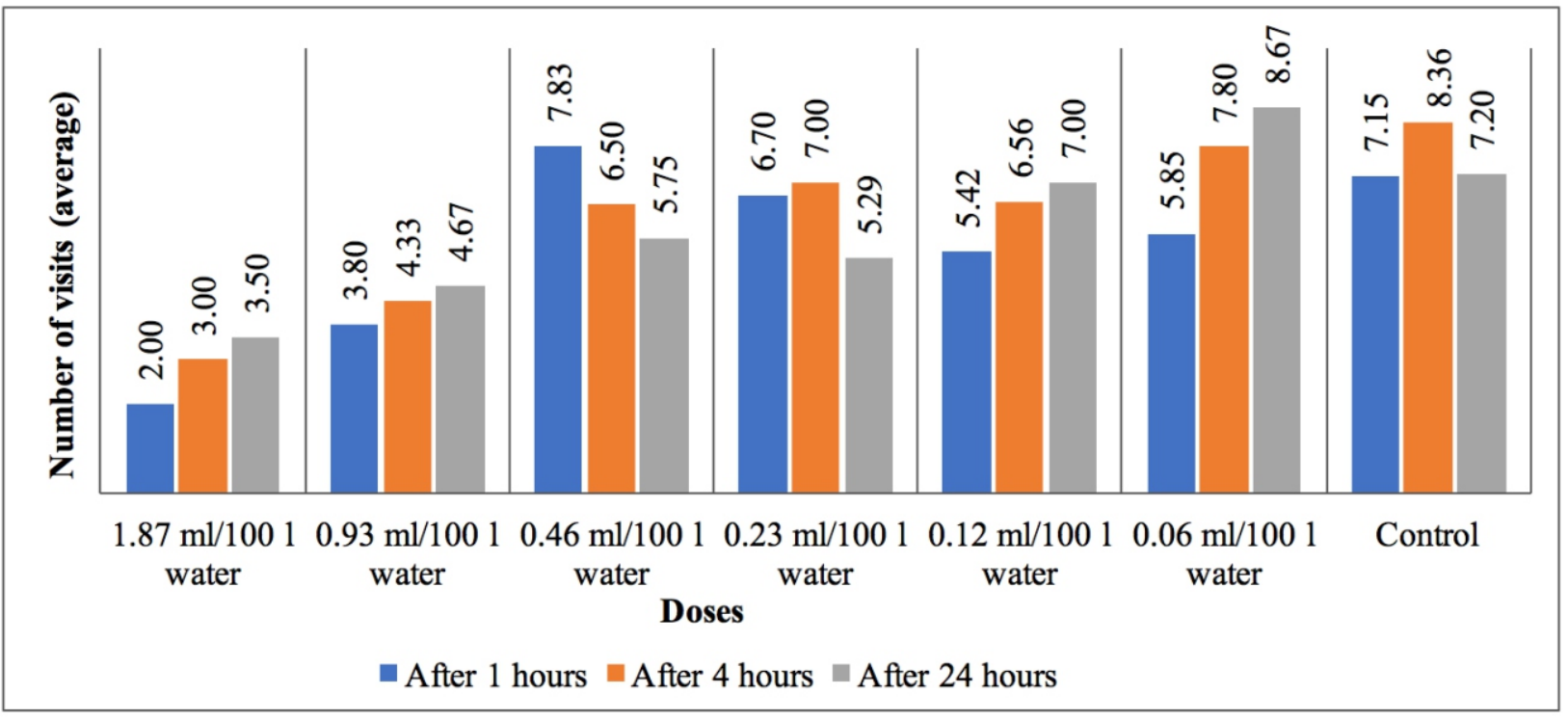

Figure 4. Depending on the dose number of visits (average).

Figure 5 shows the mean numbers of the visits to the petri dish, depending on the doses, at all observation times.

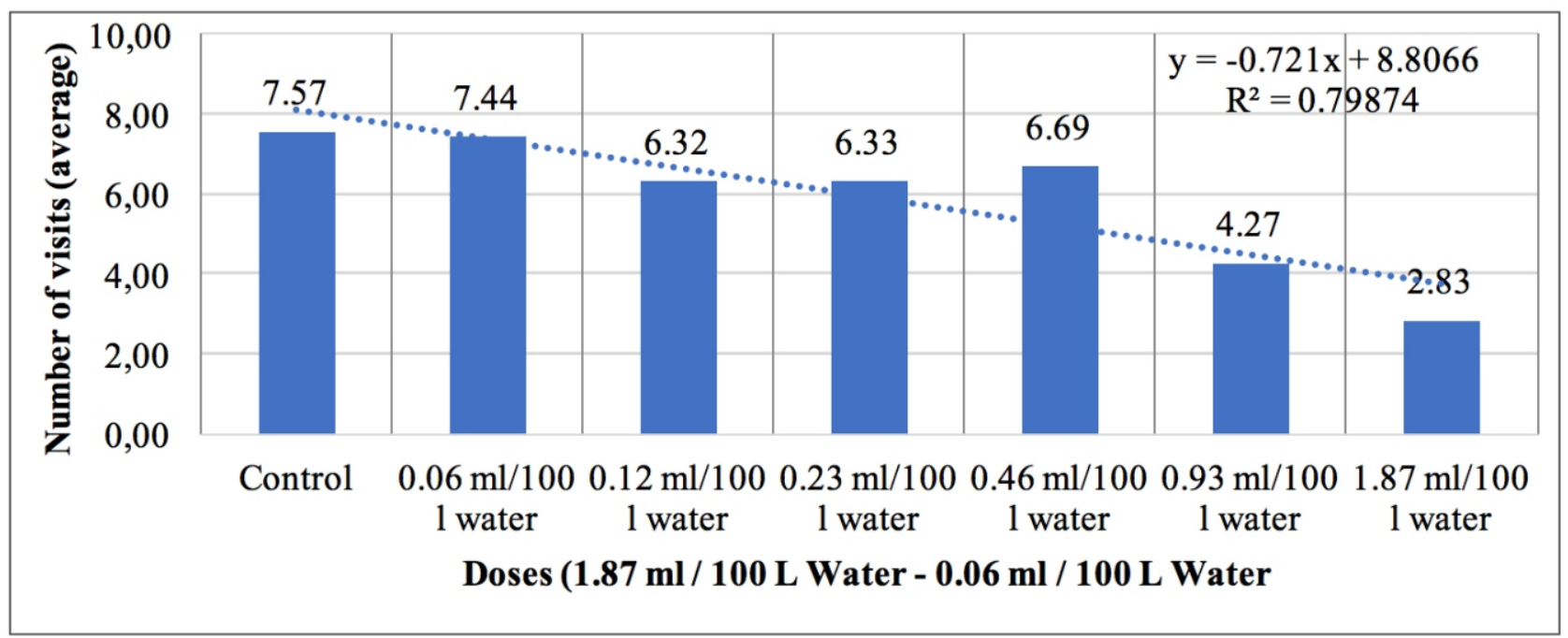

Figure 5. Average number of visits of the bees fed with different doses of Thiamethoxam.

The control group visited the petri dish by an average of 7.57 times, while those fed with the lowest dose of the pesticide $(0.06 \mathrm{ml} / 100 \mathrm{~L}$ water $)$ visited the petri dish 7.44 times. The number of visits decreased as the dose increased except $0.23 \mathrm{ml} / 100 \mathrm{~L}$ water and $0.46 \mathrm{ml} / 100 \mathrm{~L}$ water. 


\section{CONCLUSION}

All of the bees fed with the syrups prepared with the doses $15.00,7.50,3.75 \mathrm{ml} / 100 \mathrm{~L}$ water of the thiamethoxam active ingredient which is commonly used in agriculture, died. The rates of the bees returning to the petri dish and the number of visits varied after 1, 4 and 24 hours, in the other doses. The rates of returning bees showed a linear decline depending on the insecticide dose and the wild bees were found to be affected from thiamethoxam even with the lower doses used in pest control. Similarly, when all observation times were evaluated together, the number of syrup visits of the bees showed a similar pattern.

Since there was no similar study on Vespa germanica, the literature information of other bees was taken into consideration in the discussions. In recent years there is an increasing concern about the possible effects of neonicotinoid pesticides on non-target species [25]. In a study investigating neonicotinoid residues in 198 honey samples collected all around the world, it was found that $75 \%$ of the samples contained at least $1,45 \%$ of at least 2 and $10 \%$ of them contained 4 or 5 different neonicotinoid residues [26]. In a study conducted in 2016, the field where the neonicotinoid medicated oilseed crops were cultivated and the 45 plant species around this area were examined and an average of $10 \mathrm{ng} / \mathrm{g}$ neonicotinoid residue was found. Among the concentrations determined, the highest level belongs to thiamethoxam in Cirsium vulgare with $106 \mathrm{ng} / \mathrm{g}$. [27]. It can be mentioned as a result that wild bees or pollinators are very likely to meet with pesticide residues, and that bees and other pollinators take pesticide residues together with food, like human.

Nowadays, the importance of natural pollinators has become more and more evident. As the decrease in pollinators means a decrease in product yields, there is concern that this may lead to a "pollination crisis" [28].

Vespa germanica, a species of natural predator and also a wild pollinator $[29,30]$, is found in almost all regions of our country [31, 32, 33, 34]. Both the findings of our research and the literature on similar topics suggested that frequent and widespread use of neonicotinoid agrochemicals may lead to environmental pollution as well as an important ecological and economic problem.

\section{ACKNOWLEDGMENT}

We thank to Dr. John M. HRANTIZ who had taught the material and method and Prof. Dr. Gürsel KARACA of Süleyman Demirel University in Isparta, Turkey for editing the English of this manuscript.

\section{REFERENCES}

[1] Biesmeijer, J. C., Roberts, S. P., Reemer, M., Ohlemüller, R., Edwards, M., Peeters, T., Settele, J. (2006). Parallel declines in pollinators and insect-pollinated plants in Britain and the Netherlands. Science, 313(5785), 351-354.

[2] Oliver, T. H., Isaac, N. J., August, T. A., Woodcock, B. A., Roy, D. B., Bullock, J. M. (2015). Declining resilience of ecosystem functions under biodiversity loss. Nature communications, 6, 10122.

[3] Sanchez-Bayo, F. Goka, K. Pesticide residues and bees-a risk assessment. PLoS One 9, e94482 (2014).

[4] Chicas-Mosier, A. M., Cooper, B. A., Melendez, A. M., Pérez, M., Abramson, C. I. (2017). The effects of ingested aqueous aluminum on floral fidelity and foraging strategy in honey bees (Apis mellifera). Ecotoxicology and Environmental Safety, 143, 80-86.

[5] Goulson D, Nicholls E, Botías C, Rotheray E. L. 2015 Bee declines driven by combined stress from parasites, pesticides, and lack of flowers. Science 347, 1255957. (doi:10.1126/science.1255957)

[6] Garibaldi L. A, Steffan-Dewenter I, Winfree R, Aizen MA, Bommarco R, Cunningham SA, et al. (2013) Wild Pollinators Enhance Fruit Set of Crops Regardless of Honey Bee Abundance. Science 339: 1608-1611. pmid:23449997

[7] Potts, S.G, Biesmeijer J. C, Kremen C, Neumann P, Schweiger O, Kunin W.E., (2010) Global pollinator declines: trends, impacts and drivers. Trends Ecol Evol 25:345-353

[8] Blitzer E, Dormann CF, Holzschuh A, Klein AM, Rand TA, Tscharntke T (2012) Spillover of functionally important organisms between managed and natural habitats. Agric Ecosyst Environ 146:34-43

[9] Huff Hartz, K.E., Edwards, T.M. Lydy, M.J. Ecotoxicology (2017) Fate and transport of furrow-applied granular tefluthrin and seedcoated clothianidin insecticides: Comparison of field-scale observations and model estimates. 26: 876. https://doi.org/10.1007/s10646-017-1818-z Ecotoxicology September 2017, Volume 26, Issue 7, pp 876-888 
[10] Yıldırım, E. (2012a). Tarımsal Zararlılarla Mücadele Yöntemleri ve İlaçlar. 3. Bask1. Atatürk Üniversitesi Ziraat Fakültesi Yayınları No, 219, 330s. Erzurum.

[11] Jeschke P, Nauen R, Schindler M, Elbert A. 2011 Overview of the status and global strategy for neonicotinoids. J. Agric. Food Chem. 59, 2897-2908.

[12] Gajger, I.T., Sakač, M. Gregorc, A. (2017) Impact of Thiamethoxam on Honey Bee Queen (Apis mellifera carnica) Reproductive Morphology and Physiology. 99: 297. https://doi.org/10.1007/s00128-017-2144-0 Bulletin of Environmental Contamination and Toxicology September 2017, Volume 99, Issue 3, pp 297-302

[13] Mogren, C.L., Lundgren, G.J., (2016). Neonicotinoid-contaminated pollinator strips adjacent to cropland reduce honey bee nutritional status. Scientific Reports 6 , Article $\mathrm{n} \mathrm{u} \mathrm{m} \mathrm{b} \mathrm{e} \mathrm{r} \mathrm{:} 296608$ ( $\left.\begin{array}{llll}2 & 0 & 1 & 6\end{array}\right)$ doi:10.1038/srep29608

[14] Alkassab, A.T. Kirchner, W.H. J Plant Dis Prot (2017) Sublethal exposure to neonicotinoids and related side effects on insect pollinators: honeybees, bumblebees, a n d s o litary bees . 124: 1 . https://doi.org/10.1007/s41348-016-0041-0 Journal of Plant Diseases and Protection. February 2017, Volume 124, Issue 1, pp 1-30

[15] Pilling, E. Campbell P, Coulson, M, Ruddle N, Tornier, I. (2013) A Four-Year Field Program Investigating Long-Term Effects of Repeated Exposure of Honey Bee Colonies to Flowering Crops Treated with Thiamethoxam. PLoS ONE 8(10): e77193. https://doi.org/10.1371/journal.pone.007719 $\underline{3}$

[16] Henry, M., Cerrutti, N., Aupinel, P., Decourtye, A., Gayrard, M., Odoux, J. F., Bretagnolle, V. (2015, November). Reconciling laboratory and field assessments of neonicotinoid toxicity to honeybees. In Proc. R. Soc. B (Vol. 282, No. 1819, p. 20152110). The Royal Society.

[17] Wood, T.J. Goulson, D. Environ Sci Pollut Res (2017). The environmental risks of neonicotinoid pesticides: a review of the evidence post 2013.24: 17285. https://doi.org/10.1007/s11356-017-9240-x. July 2017, Volume 24, Issue 21, pp

[18] Brandt A, Gorenflo A, Siede R, Meixner M, Büchler R (2016) The neonicotinoids thiacloprid, imidacloprid, and clothianidin affect the immunocompetence of honey bees (Apis mellifera L.). J Insect Physiol 86:40-47

[19] Arena M, Sgolastra F (2014) A meta-analysis comparing the sensitivity of bees to pesticides. Ecotoxicology 23:324-334

[20] Tooming, E., Merivee, E., Must, A. (2017) Behavioural effects of the neonicotinoid insecticide thiamethoxam on the predatory insect Platynus assimilis. 26: 902. https://doi.org/10.1007/s10646-017-1820-5 Ecotoxicology September 2017, Volume 26, Issue 7, pp 902-913

[21] Anlaş, S, Tezcan, S , Yıldırım, E . (2009). An Evaluation on Hymenoptera (Insecta) Fauna Collected by Pitfall Traps at Bozda Mountains of Western Turkey. Yüzüncü Y1l Üniversitesi Tarım Bilimleri Dergisi, 19 (1), $23-32$. R e t r i e v e d f r o m http://dergipark.gov.tr/yyutbd/issue/21985/236060

[22] Tüzün, A., Kekillioğlu, A., 2003.Ankara Vespidae (Insecta:Hymenoptera) Türleri Türleri Üzerine Sistematik, Faunistik Çalışmalar ve Ekolojik Gözlemle, FenEdebiyat Fakültesi, Fen Dergisi, Sayı: 22, S.97-105.

[23] Karahan, A., Karaca, İ. (2016). Adana ve Konya İllerindeki Arıcılık Faliyetleri ve Koloni Kayıpları. Süleyman Demirel Üniversitesi Fen Bilimleri Enstitüsü Dergisi, 20 ( 2 ). R e t r i e v e d f r o m http://dergipark.gov.tr/sdufenbed/issue/2391 6/254877

[24] Seeley T. D., (1995) The wisdom of the hive: the social physiology of honey bee colonies. Harvard University Press, Cambridge.

[25] Rundlöf, M, Andersson GKS, Bommarco R et al (2015) Seed coating with a neonicotinoid insecticide negatively affects wild bees. Nature. doi:10.1038/nature 14420

[26] Mitchell, E. A. D., Mulhauser, B., Mulot, M., Mutabazi, A., Glauser, G., \& Aebi, A. (2017). A worldwide survey of neonicotinoids in honey. Science, 358(6359), 109-111.

[27] Botías C, David A, Hill E, Goulson, D (2016) Contamination of wild plants near neonicotinoid seed-treated crops, and implications for non-target insects. Sci Total Environ 566-567:269-278

[28] Goulson D, Nicholls E, Botías C, Rotheray EL. 2015 Bee declines driven by combined stress from parasites, pesticides, and lack of flowers. Science 347, 1255957. 
[29] Memmott, J., Waser, N. M. (2002). Integration of alien plants into a native flower-pollinator visitation web. Proceedings of the Royal Society of London B: Biological Sciences, 269(1508), 23952399.

[30] Jacobs, J. H., Clark, S. J., Denholm, I., Goulson, D., Stoate, C., Osborne, J. L. (2010). Pollinator effectiveness and fruit set in common ivy, Hedera helix (Araliaceae). Arthropod-Plant Interactions, 4(1), 19-28.

[31] Yildirim, E., Gusenleitner, J. (2001). The present situation of the Vespidae-fauna (Hymenoptera, Aculeata) of Turkey.

[32] Tezcan, S., Karsavuran, Y., Pehlivan, E., Anlaş, S., Yildirim, E. (2005). Contribution To The Knowledge Of Vespidae (Hymenoptera: Aculeata) Fauna Of Turkey. Turkish Journal Of Entomology, 29(2)

[33] Japoshvili, G., Karaca, İ. (2010). List of Vespidae, Scoliidae and Tiphiidae (Hymenoptera) of Gölcük Natural Park in Isparta Province, Turkey. SDÜ Fen Dergisi, $5(2)$.

[34] Yildirim, E. (2012b). The distribution and biogeography of Vespidae (Hymenoptera: Aculeata) in Turkey. Turkish Journal of Entomology, 36(1). 